\title{
Sistemik Antibiyotikler
}

\section{Doç. Dr. Zennure Takcı}

VM Medical Park Samsun Hastanesi, Dermatoloji Kliniği, Samsun, Türkiye

Öz

Sistemik antibiyotikler topikal tedavilere dirençli, yaygın, enflamatuvar orta ve şiddetli akne tedavisinin temelini oluşturur. Tetrasiklin grubu antibiyotikler orta ve şiddetli aknede birinci basamak tedaviyi oluştururken, ikinci seçenek makrolid grubu sistemik antibiyotiklerdir. Tetrasiklin ve makrolid grubu antibiyotikler dışında sistemik antibiyotik kullanımı zorunlu olmadıkça tercih edilmemelidir. Sistemik antibiyotiklerde etkinlik 1 aydan sonra ortaya çıkar, 6-8 haftada yanıt alınamadıysa tedavi değiştirilmeli ve hiçbir zaman idame tedavi için kullanılmamalıdır. Akne tedavisinde sistemik antibiyotik kullanımıyla ilgili en önemli sorun bakteriyel direnç gelişimi ve ilacın zaman içinde etkisizleşmesidir.

Anahtar Kelimeler: Akne, antibiyotik, antibiyotik direnci, doksisiklin, makrolidler, tetrasiklin

\section{Abstract}

Systemic antibiotics form the basis for the treatment of topical treatment-resistant, diffuse, inflammatory, moderate and severe acne. While the tetracycline group of antibiotics constitute the first line of treatment in moderate and severe acne, a second option could be the macrolide group of systemic antibiotics. Other than tetracycline and macrolide groups of antibiotics, use of systemic antibiotics should be avoided unless absolutely necessary. Systemic antibiotics show their action after a month; if no response is achieved within 6-8 weeks, the therapy should be changed and never be used for maintenance treatment. The main problem of using systemic antibiotics in the treatment of acne is the development of bacterial resistance and the drug becoming ineffective in time.

Keywords: Acne, antibiotics, antibiotic resistance, doxycycline, macrolids, tetracycline

\section{Giriş}

Sistemik antibiyotikler orta ve şiddetli akne, topikal tedavilere dirençli enflamatuvar akne ve trunkal akne gibi yaygın ve şiddetli formlarda akne tedavisinin temelini oluşturur. Kanıtlar tetrasiklin, doksisiklin, minosiklin, eritromisin, azitromisin, trimetoprim/sulfametoksazol, amoksisilin ve sefaleksinin etkinliğini desteklemektedir ${ }^{1}$. Antibiyotikler bir yandan $P$. acnes sayısını azaltırken, diğer yandan konağın enflamatuvar cevabını baskılayarak etki eder ${ }^{1,2}$. Tetrasiklin grubu antibiyotikler kontrendike olmadıkları sürece orta ve şiddetli aknede birinci basamak tedaviyi oluşturur. Kontrendikasyon veya tolere edilemeyen yan etki varlığında ikinci seçenek makrolid grubu sistemik antibiyotiklerdir (eritromisin, azitromisin). Tetrasiklin ve makrolid grubu antibiyotikler dışında sistemik antibiyotik kullanımı mecbur kalınmadıkça tercih edilmemelidir ${ }^{2}$. Sistemik antibiyotiklerde etkinlik bir aydan sonra ortaya çıkar, 6-8 haftada yanıt alınamadıysa tedavi değiştirilmelidir. Kullanılan antibiyotik ile istenen etki elde edildiğinde tedavi kesilerek topikal ajanlarla idame tedavisine geçilmeli, sistemik antibiyotikler idame tedavi için kullanılmamalıdır. Tedavi tekrarlanacaksa daha

Yazıșma Adresi/Address for Correspondence: Doç. Dr. Zennure Takcı

VM Medical Park Samsun Hastanesi, Dermatoloji Kliniği, Samsun, Türkiye

E-posta: drzennure80@yahoo.com ORCID: orcid.org/0000-0001-7257-5792

(c) Telif Hakkı 2020 Deri ve Zührevi Hastalılar Derneği

Türkderm - Türk Deri Hastalıkları ve Frengi Arșivi, Galenos Yayınevi tarafından basılmıștır. 
önce etkili olan ajan tercih edilmeli, yanıt yetersizliği durumunda diğer antibiyotik grupları düşünülmelidir ${ }^{1-3}$. Sistemik antibiyotik tedavisi ile ilgili öneriler Tablo 1'de özetlenmiş, tedavi ajanlarının doz, yan etki ve kontrendikasyon profilleri Tablo 2'de detaylı olarak belirtilmiştir.

\section{Bakteriyel direnç gelişimi}

Akne tedavisinde sistemik antibiyotik kullanımıla ilgili en önemli sorun bakteriyel direnç gelişimi ve ilacın zaman içinde etkisizleşmesidir. Birçok ülke $P$. acnes suşlarının \%50'sinden fazlasının topikal makrolidler (eritromisin) başta olmak üzere antibiyotik direnci geliştirdiğini ve bunun tedavi başarısında azalmaya neden olduğu halk sağlığı problemine dikkat çekmektedir".

Topikal antibiyotik kullanımının neden olduğu bakteriyel direnç uygulama bölgesinde sınırlı iken sistemik antibiyotikler deride ve diğer sistemlerde normal vücut florasını etkileyerek bakteriyel direnç gelişiminin yanında fırsatçı patojenlerin çoğalmasına ve doğal mikrobiyatanın bozulmasına neden olur. Akne etiyopatogenezinde suçlanan $P$. acnes yanında Staphylococcus aureus, koagülaz-negatif Staphylococcus ve Grup A Streptococcus gibi konakta bulunan diğer miroorganizmalarda da direnç gelişimi bildirilmiştir. Metisiline dirençli S. aureus ve S. pyogenes'ye bağlı enfeksiyonlar toplum sağlığını tehdit etmektedir. Dirençli deri florası oluşan hastalar rezervuar rol oynayarak dirençli suşları temasla aile bireylerine, arkadaşlarına ve muayene eden sağlık personeline de bulaştırabilmektedir ${ }^{5-7}$.

Direnç gelişimi ve normal mikrobiyatada bozulma yanında akne tedavisinde uzun süre antibiyotik kullananların enfeksiyonlara yatkın olabileceği hipotezi öne sürülmektedir. En az altı hafta süreyle topikal veya sistemik antibiyotik tedavisi alan 100.000 'den fazla akne hastasını inceleyen retrospektif kohort çalışmasında, bir yıllık izlemde hastaların üst solunum yolu enfeksiyonuna daha yatkın olduğu bildirilmiştir ${ }^{8}$. Prospektif bir kohort çalışmasında akne tedavisi nedeniyle sistemik oral antibiyotik kullanan öğrencilerin bir yıllık izlemde antibiyotik kullanmayanlara göre dört kat daha fazla farenjit geçirdikleri saptanmıştır ${ }^{9}$. Ayrıca akne tedavisinde uzun süre tetrasiklin grubu başta olmak üzere antibiyotik kullanımının enflamatuvar bağırsak hastalıkları, minosiklinin indüklediği lupus gibi kolajen vasküler hastalıklar, artmış meme ve kolon kanseri riski ile arasında ilişki olabileceği bildirilmektedir ${ }^{10-15}$.

Bakteriyel direnç gelişimini engelleyici önlemler Tablo 1'de verilmektedir ${ }^{16,17}$.

\section{Tetrasiklinler}

- Orta ve şiddetli enflamatuvar akne tedavisinde birinci basamak tedavi ajanlarıdır. Bu grupta tetrasiklin, doksisiklin, minosiklin, limesiklin ve yeni çıkan, çalışmaları devam eden saresiklin yer almaktadır. Bu rehberde ülkemizde kullanılabilen tetrasiklin ve doksisikline değinilmektedir. Doksisiklin ve minosiklinin etkinlikleri benzer olup tetrasiklinden daha etkilidirler. Günümüzde akne vulgaris tedavisinde ilk tercih edilecek antibiyotik doksisiklindir-3.

- Tetrasiklin lipofilik yapısı nedeniyle pilosebase ünite kolayca penetre olur. Bakteriyel ribozomun $30 \mathrm{~S}$ alt birimini bağlayarak protein sentezini inhibe ederek bakteriyostatik etki gösterir. Kemotaksi ve metalloproteinaz aktivitesini inhibe etme dahil olmak üzere belirgin anti-enflamatuvar etkiye sahiptir. Serbest oksijen radikallerini temizleyici ve antikolajenolitik özellikleri de bulunmaktadır ${ }^{1-3}$.

- Tetrasiklin aç karnına bol su ile alınmalı, mümkünse aldıktan sonra en az iki saat uyunmamalıdır. Kalsiyum içeren yiyecekler (özellikle süt ürünleri), anti-asitler (alüminyum, bizmut, kalsiyum ve magnezyum), çinko bileşikleri ve demir tetrasiklinin emilimini azaltmaktadır.

- Doksisiklin yemekle birlikte alınabilir. Doksisiklin karaciğerde metabolize olduğu için böbrek yetmezliği olan hastalarda güvenle tercih edilebilir, enterik kaplı formu daha az gastrointestinal yan etkiye neden olmasıyla daha iyi tolere edilir.

- Doksiklin 100-200 mg/gün dozda önerilmekle birlikte genellikle günde tek doz 100 mg yeterli olmaktadır. Yapılan bir çalışmada günde iki kez 20 mg/gün subantimikrobiyal doksisiklinin plasebodan üstün olduğu ve 100 mg doksisikline benzer etki ettiği gösterilmiştir. Doksisiklinin yurtdışında bulunan 40 mg'lik subantimikrobiyal dozu ülkemizde bulunmamaktadır ${ }^{1-3,18}$

- Tetrasiklin bölünmüş dozlarda 500-1.000 mg/gün dozda (sekiz yaş üstü çocuklarda günde 25-50 mg/kg) önerilmektedir. Bir-iki hafta içinde yanıt alınırsa 125-500 mg/gün'e düşürülebilir ${ }^{1-3,18}$.

- Tetrasiklin kesilip sistemik izotretinoin tedavisine başlanacak hastalarda her iki ilaç da psödotümör serebriye yol açabileceği için tetrasiklinin vücuttan atılma süresi kadar (yaklaşık yedi gün) beklenilmesi önerilir ${ }^{19}$.

- Tetrasiklin bulantı, kusma, diyare, karında şişkinlik gibi hafif gastrointestinal semptomlar, siyah kıllı dil, kandidiyazis, fototoksisite, özefajit, özefagial ülserasyon, benign intrakraniyal hipertansiyon, karaciğer toksisitesi, dişte kalıc diskolorasyon ve enamel hipoplazisi, deride aşırı duyarlılık reaksiyonu eritrodermi, makülopapüler döküntü, onikolizis ve tırnak diskolorasyonu yapabilmektedir ${ }^{1-3,18,20}$.

- Doksisiklin tetrasikline göre daha az olmakla birlikte hafif gastrointestinal şikayetler, fototoksisite, fotoonikolizis ve hipersensitivite reaksiyonlarına neden olabilir ${ }^{1-3,18,20}$.

- Tetrasiklin ve doksisiklin gebelik, laktasyon, sekiz yaşından küçükler, ilaca karşı alerjisi olanlarda kontrendikedir.

\section{Tablo 1. Akne vulgaris tedavisinde sistemik antibiyotik kullanım önerileri}

- Sistemik antibiyotik endikasyonları; orta ve şiddetli akne, topikal tedavilere dirençli enflamatuvar akne ve trunkal akne gibi geniş alanları kaplayan aknedir.

- ilk seçenek sistemik antibiyotik doksisiklindir.

- Oral eritromisin ve azitromisin direnç gelişimi nedeniyle ilk tercih olmamalıdır. Tetrasiklin grubu antibiyotiklerin kontrendike (gebelik veya sekiz yaş altı gibi) olduğu veya kullanılamadığı durumlarda tercih edilmelidir.

- Tetrasiklin ve makrolid grubu antibiyotikler dışında sistemik antibiyotik kullanımı yetersiz veri nedeniyle önerilmemektedir.

- Sistemik antibiyotik tedavisi mümkün olan en kısa sürede sonlandırılmalıdır, tedavi süresinin üç ayı geçmemesi önerilir. Altı-sekiz haftada yanıt

alınamayan hastalarda tedavi sonlandırımalı ve farklı bir tedaviyle değiştirilmelidir.

- Sistemik antibiyotikler tek başına kullanılmamalı, her zaman topikal retinoid ve/veya BPO ile kombine edilmelidir.

- Aynı anda farklı gruptan topikal ve sistemik antibiyotik kullanılmamalıdır.

- Tekrar sistemik antibiyotik tedavisi başlanacaksa daha önce etkili olan ajan başlanmalı, yetersiz olursa diğer gruplar tercih edilmelidir.

BPO: Benzoil peroksit 


\section{Makrolidler}

- Tetrasiklin grubuna intolerans veya kontrendikasyon varlığında tercih edilmelidir. Eritromisin, azitromisin ve roksitromisin akne tedavisinde etkili makrolidlerdir. Eritromisinin direnç ve gastrointestinal yan etki potansiyeli yüksektir, ülkemizde satışta olmadığından kullanılamamaktadır ${ }^{1-3}$.

Tablo 2. Sistemik antibiyotiklerin doz, yan etki ve kontrendikasyon profilleri

\begin{tabular}{|c|c|c|c|c|}
\hline & Doz & Yan etki & Kontrendikasyon & $\begin{array}{l}\text { Gebelik } \\
\text { kategori }\end{array}$ \\
\hline Tetrasiklin & $\begin{array}{l}\text { Çocuk: }(>) \\
25-50 \mathrm{mg} / \mathrm{kg} / \mathrm{gün}, \\
\text { bölünmüş } 4 \text { doz halinde } \\
\text { Erişkin: } 1 \mathrm{gr} / \text { gün bölünmüş } \\
2 \text { doz halinde } \\
\text { Bir-iki hafta içinde yanıt } \\
\text { alınırsa doz azaltılarak } \\
125-500 \text { mg/gün şeklinde } \\
\text { idame dozuna düşürülebilir. }\end{array}$ & $\begin{array}{l}\text { Gastrointestinal: Bulantı, kusma, diyare, karında şişkinlik, glossit, } \\
\text { siyah kıllı dil, oral-anogenital kandidiyazis, özefajit veya özefagial } \\
\text { erozyon } \\
\text { Diş: Kalııı diskolorasyon, enamel hipoplazisi } \\
\text { Deri: Makülopapüler döküntü, eritrodermi, fotosensitivite, } \\
\text { fototoksisite, onikolizis, tırnak diskolorasyonu } \\
\text { Renal: Doz bağımlı olarak kanda üre yüksekliği } \\
\text { Karaciğer: Hepatotoksik, karaciğer yetmezliği } \\
\text { Hematolojik sistem: Hemolitik anemi, trombositopeni, } \\
\text { nötropeni, eozinofili } \\
\text { Hipersensitivite reaksiyonları: Ürtiker, anjiyoödem, anafilaksi, } \\
\text { serum hastalığı benzeri reaksiyon } \\
\text { Diğer: İntrakraniyal basınç artışı }\end{array}$ & $\begin{array}{l}\text { Tetrasiklin grubuna } \\
\text { karşı aşııı duyarlıık } \\
\text { Sekiz yaşından } \\
\text { küçükler } \\
\text { Gebelik } \\
\text { Laktasyon }\end{array}$ & Kategori D \\
\hline Doksisiklin & $\begin{array}{l}\text { Çocuk: (>8) } \\
4,5 \mathrm{mg} / \mathrm{kg} \text { bölünmüş } 2 \mathrm{doz} \\
\text { halinde ilk gün, bölünmüş } \\
\text { veya tek doz halinde } 2,25 \\
\mathrm{mg} / \mathrm{kg} / \mathrm{gün} \text { şeklinde devam } \\
\text { Erişkin: } 100-200 \mathrm{mg} / \mathrm{gün} \\
\text { (ilk gün } 2 \times 100 \mathrm{mg} / \mathrm{gün}, \\
\text { devamında } 100 \mathrm{mg} / \text { gün }\end{array}$ & Tetrasikline göre daha az olmakla birlikte aynı yan etki profili & $\begin{array}{l}\text { Tetrasiklin grubuna } \\
\text { karşı aşırı duyarlılık } \\
\text { sekiz yaşından } \\
\text { küçükler } \\
\text { Gebelik } \\
\text { Laktasyon }\end{array}$ & Kategori D \\
\hline Eritromisin & 500 mg, günde iki kez & $\begin{array}{l}\text { Gastrointestinal: Bulantı, kusma, iştahsızlık, karın ağrısı, diyare } \\
\text { Karaciğer: Hepatit, hepatik disfonksiyon } \\
\text { Kardiyovasküler: Ventriküler taşikardi, QT uzaması } \\
\text { Deri: Hafif döküntü, EM, SJS, TEN, ürtiker, anafilaksi }\end{array}$ & $\begin{array}{l}\text { İlaca karşı aşırı } \\
\text { duyarlıık } \\
\text { Terfenadin, } \\
\text { astemizol, pimozit, } \\
\text { sisaprit kullanan } \\
\text { hastalar }\end{array}$ & Kategori B \\
\hline Azitromisin & 500 mg/haftada üç gün & $\begin{array}{l}\text { Gastrointestinal: Bulantı, kusma, dispepsi, karın ağrısı, } \\
\text { diyare, psödomembranöz enterokolit, melena, kandida, dilde } \\
\text { diskolorasyon } \\
\text { Kardiyovasküler: Çarpıntı, ventriküler taşikardi, QT uzaması } \\
\text { Karaciğer: Hepatik disfonksiyon, kolestatik sarııı } \\
\text { Genitoüriner: Monilya, vajinit, nefrit, akut böbrek yetmezliği } \\
\text { Deri: Kaşıntı, EM, SJS, TEN, döküntü, pruritus, fotosensitivite, } \\
\text { anjiyoödem } \\
\text { SSS: Vertigo, konvülsiyon, baş ağrısı, işitme kaybı, hiperaktivite, } \\
\text { ajitasyon } \\
\text { Kan: Trombositopeni }\end{array}$ & $\begin{array}{l}\text { Makrolidlere karşı } \\
\text { aşırı duyarlıık } \\
\text { Önceden } \\
\text { azitromisin } \\
\text { kullanımına bağlı } \\
\text { kolestatik sarılık } \\
\text { veya hepatik } \\
\text { disfonksiyon } \\
\text { öyküsü varlığı }\end{array}$ & Kategori B \\
\hline TMP-SMX & 300 mg/gün & $\begin{array}{l}\text { Gastrointestinal: Bulantı, kusma, karın ağıısı, iştahsızlık, hepatit, } \\
\text { fulminan hepatik nekroz pankreatit, stomatit } \\
\text { Deri ve alerjik reaksiyon: EM, SJS, TEN, kaşıntı, ürtiker, } \\
\text { anjiyoödem, anafilaksi, jeneralize eritemli döküntü, eritrodermi, } \\
\text { fotosensitivite, kutanöz vaskülit, PAN, SLE } \\
\text { Renal: Renal disfonksiyon, böbrek yetmezliği, interstisyel nefrit } \\
\text { Kas-iskelet: Artrit, artralji, rabdomiyoliz } \\
\text { Pulmoner: Nefes darlığı, öksürük, pulmoner infiltratlar } \\
\text { Kan: Agranülositoz, aplastik anemi, trombositopeni, lökopeni, } \\
\text { hemolitik anemi, megaloblastik anemi, methemoglobibemi, } \\
\text { eozinofili } \\
\text { Nöropsikiyatrik: Aseptik menenjit, konvülsiyon, periferal nörit, } \\
\text { ataksi, baş dönmesi, kulak çınlaması, baş ağrısı, halüsinasyon, } \\
\text { depresyon }\end{array}$ & $\begin{array}{l}\text { İlaca karşı aşırı } \\
\text { duyarlıık } \\
\text { Hepatik-renal } \\
\text { yetmezlik } \\
\text { Gebelik } \\
\text { Laktasyon } \\
\text { Megaloblastik } \\
\text { anemi iki aydan } \\
\text { küçük bebekler }\end{array}$ & $\begin{array}{l}\text { Kategori C } \\
\text { Yenidoğanda } \\
\text { kernikterusa } \\
\text { neden } \\
\text { olabilir }\end{array}$ \\
\hline
\end{tabular}


- Makrolidler bakteriyel ribozomun 505 subünitine bağlanarak bakteriyostatik etki gösterir. Anti-enflamatuvar özellikleri tetrasiklinlere göre daha azdır ${ }^{1-3,18}$.

- Azitromisin en sık haftada üç ardışık gün bir kez 500 mg şeklinde kullanılabileceği gibi; 1 . ay haftada üç gün, 2. ay haftada iki gün ve 3 . ay haftada bir gün şeklinde de uygulanabilir. Ortalama üç ay kullanım önerilmektedir ${ }^{1-3,18}$. Roksitromisin günde iki kez 150 mg (dört haftayı geçmemeli) şeklinde kullanıır.

- En sık doza bağımlı motiliteyi artırması sonucu abdominal kramplar, bulantı, kusma, diyare gibi gastrointestinal yan etkiler görülür. Hepatotoksisite, ventriküler taşikardi, aritmi, QT uzaması gibi kardiyak yan etkileri vardır. Karaciğerde sitokrom P450 enzim fonksiyonlarını bozması ve ilaç metabolizmasını yavaşlatması nedeniyle ilaç etkileşimlerine dikkat edilmelidir. Nörolojik sistemde vertigo, konvülsiyon, baş ağrısı, işitme kaybı gibi istenmeyen etkiler oluşabilir. Azitromisin fotosensitiviteye neden olmaz, yan etkilerinin az ve doz aralıklarının uzun oluşu önemli avantajlarıdır. Nadiren hipersensitivite reaksiyonları gelişebilirr ${ }^{1-3,18,20}$. Makrolid antibiyotiklere karşı hipersensitivite, karaciğer disfonksiyonu ve eşlik eden ergo alkaloidi kullanımı varlığında kullanılmamalıdır.

- Eritromisin ve azitromisin gebelikte ve emzirenlerde güvenle kullanılabilir.

\section{Diğer antibiyotikler}

- Trimetoprim/sulfametoksazol günümüzde akne tedavisinde önceliğini yitirmiş olup tetrasiklin veya makrolidlerin kullanılamadığı durumlarda, özellikle de Gram-negatif folikülitte tercih edilmektedir. Çok sayıda yan etkisi (hepatotoksisite, nefrotoksisite, hematolojik ve nörolojik sorunlar, Stevens-Johnson sendromu ve toksik epidermal nekrolizis gibi hipersensitivite reaksiyonları vb.) olup gebelerde kullanılmamalıdır. - Penisilin ve sefalosporinlerin (sefaleksin) akne tedavisinde kullanımıyla ilgili verilerin oldukça kısıtlı olmasına karşın gebelerde ve diğer ilaçlara karşı alerjisi olanlarda alternatif seçenek olarak nadiren kullanılabilmektedir ${ }^{1-3,18,20,21 .}$.

\section{Kaynaklar}

1. Zaenglein AL, Pathy AL, Schlosser BJ, et al: Guidelines of care for the management of acne vulgaris. J Am Acad Dermatol 2016;74:945-73.

2. Thiboutot DM, Dreno B, Abanmi A, et al: Practical management of acne for clinicians: An international consensus from the Global Alliance to Improve Outcomes in Acne. J Am Acad Dermatol 2018;78:S1-S23-e21.
3. Gollnick HP, Bettoli V, Lambert J, et al: A consensus-based practical and daily guide for the treatment of acne patients. J Eur Acad Dermatol Venereol 2016;30:1480-90.

4. Walsh TR, Efthimiou J, Dréno B: Systematic review of antibiotic resistance in acne: an increasing topical and oral threat. Lancet Infect Dis 2016;16:23-33.

5. Dessinioti C, Katsambas A: Propionibacterium acnes and antimicrobial resistance in acne. Clin Dermatol 2017;35:163-7.

6. Patel $M$, Bowe $W$, Heughebaert $C$, Shalita AR: The development of antimicrobial resistance due to the antibiotic treatment of acne vulgaris: A review. J Drugs Dermatol 2010:9:655-64.

7. Adler BL, Kornmehl H, Armstrong AW: Antibiotic resistance in acne treatment. JAMA Dermatol 2017;153:810-1.

8. Margolis DJ, Bowe WP, Hoffstad O, Berlin JA: Antibiotic treatment of acne may be associated with upper respiratory tract infections. Arch Dermatol 2005;141:1132-6.

9. Margolis DJ, Fanelli M, Kupperman E, et al: Association of pharyngitis with oral antibiotic use for the treatment of acne: A cross-sectional and prospective cohort study. Arch Dermatol 2012;148:326-32.

10. Margolis DJ, Fanelli M, Hoffstad O, Lewis JD: Potential association between the oral tetracycline class of antimicrobials used to treat acne and inflammatory bowel disease. Am J Gastroenterol 2010;105:2610-6.

11. Margolis DJ, Hoffstad O, Bilker W: Association or lack of association between tetracycline class antibiotics used for acne vulgaris and lupus erythematosus. $\mathrm{Br} J$ Dermatol 2007;157:540-6.

12. Friedman GD, Oestreicher N, Chan J, Quesenberry CP Jr., Udaltsova N, Habel LA. Antibiotics and risk of breast cancer: up to 9 years of follow-up of 2.1 million women. Cancer Epidemiol Biomarkers Prev 2006;15:2102-6.

13. Zhang H, García Rodríguez LA, Hernández-Díaz S: Antibiotic use and the risk of lung cancer. Cancer Epidemiol Biomarkers Prev 2008;17:1308-15.

14. Garrett JPD, Margolis DJ: Impact of long-term antibiotic use for acne on bacterial ecology and health outcomes: a review of observational studies. Current Dermatology Reports 2012;1:23-8.

15. Bienenfeld A, Nagler AR, Orlow SJ: Oral antibacterial therapy for acne vulgaris: an evidence-based review. Am J Clin Dermatol 2017;18:469-49.

16. Barbieri JS, Spaccarelli N, Margolis DJ, James WD: Approaches to limit systemic antibiotic use in acne: Systemic alternatives, emerging topical therapies, dietary modification, and laser and light-based treatments. J Am Acad Dermatol 2019;80:538-49.

17. Dreno $B$, Thiboutot $D$, Gollnick $H$, et al: Antibiotic steward ship in dermatology: limiting antibiotic use in acne. Eur J Dermatol 2014;24:330-4.

18. Leyden JJ, Del Rosso JQ: Oral antibiotic therapy for acne vulgaris: Pharmacokinetic and pharmacodynamic perspectives. J Clin Aesthet Dermatol 2011:4:40-7.

19. Caruana DM, Wylie G: 'Washout' period for oral tetracycline antibiotics prior to systemic isotretinoin. Br J Dermatol 2016;174:929-30.

20. Tripathi SV, Gustafson CJ, Huang KE, Feldman SR: Side effects of common acne treatments. Expert Opin Drug Saf 2013;12:39-51.

21. Kraft J, Freiman A: Management of acne. CMAJ 2011;183:E430-5. 